\title{
Nauczyciel w koncepcii edukacyjnej analizy transakcyjnej
}

\author{
A Teacher in Educational \\ Transactional Analysis
}

\begin{abstract}
ABSTRAKT
Problematyka edukacyina pojawiła się wcześnie w obszarze zainteresowań analizy transakcyjnej (AT). Jeden z pierwszych artykułów na ten temat dotyczył podobieństw i różnic między pracq psychoterapeuty i nauczyciela. Od tamtej pory nauczyciel oraz jego psychologiczne funkcjonowanie osobiste i zawodowe stało się też przedmiotem zarówno zagranicznych, jak i polskich interesujacych prac badawczych, które bez przesady określić można wręcz wspólnym mianem pedeutologii AT. Przywołanie owych dokonań, z reguły mniej znanych w polskiej pedagogice, stało się głównym celem niniejszego artykułu.

Zaprezentowano w nim dorobek Zespołu Badawczego Edukacyinej Analizy Transakcyinej w Akademii im. Jana Długosza w Częstochowie. Walor edukacyinej analizy transakcyjnej w przygotowaniu zawodowym nauczycieli oraz wychowawców dostrzegły dwie czołowe przedstawicielki tego nurtu na świecie: Sylvia Schachner i Susannah Temple, których poglaqdy zaprezentowano w tym artykule. Śledzqc zakres i charakter polskich publikacji dotyczqcych nauczyciela na gruncie AT, można mieć nadzieję, że znajdq one swoje kontynuacje w dalszych poszukiwaniach badawczych, odnajdując w ten sposób swoje miejsce jako jeden z dostrzegalnych nurtów polskiej psychopedagogiki i pedeutologii.
\end{abstract}

SLOWA KLUCZOWE

analiza transakcyina, edukacyina analiza transakcyina, modele edukacyine Sylvii Schachner, płynność funkcjonalna Susannah Temple

\section{KEYWORDS}

transactional analysis, educational transactional analysis, Sylvia Schachner's educational models, Susannah Temple's Functional Fluency

SPI Vol. 21, 2018/2

ISSN 2450-5358

e-ISSN 2450-5366

DOI: 10.12775/SPI.2018.2.007

Nadestano: 22.03.2018

Zaakceptowano: 17.04.2018

Artykuły i rozprawy 


\section{ABSTRACT}

Transactional analysis became interested in education relatively early. One of the first articles from this area discussed similarities and differences between work of a psychotherapist and a teacher. Since then teachers and their psychological functioning in private and professional dimensions have become the focus of valuable international and Polish studies, which can even be described as pedeutology of transactional analysis. The aim of the paper is to report these - unfortunately, not well-known - achievements.

The paper also presents the activity of the Research Team of Educational Transactional Analysis from Jan Długosz University in Częstochowa. A beneficial role of educational transactional analysis in teacher training was noticed by two renowned representatives of TA: Sylvia Schachner and Susannah Temple, whose ideas are also summarised in the paper. Outlining the scope and nature of Polish scientific papers devoted to teachers in TA, the Author hopes that they will be continued and will mark their place in Polish psychopedagogy and pedeutology.

Refleksja i badania dotyczące nauczycieli zajmują istotne miejsce $\mathrm{w}$ teorii i praktyce edukacyjnych aplikacji analizy transakcyjnej - EAT (ang. educational transactional analysis - ETA). Trzeba bowiem zauważyć, że zapoczątkowana w połowie ubiegłego wieku przez amerykańskiego psychiatrę i psychoterapeutę Erica Berne’a (1910-1970) nowa koncepcja terapii grupowej, występująca odtąd pod nazwą analizy transakcyjnej - AT (ang. transactional analysis TA), zyskała dość szybko zastosowania odnoszące się do pedagogiki. Sam jej twórca zdefiniował ten odmienny od innych nurt pomocy psychologicznej niezwykle szeroko jako „teoria działania społecznego" (theory of social action), co pozwoliło uwzględnić w nim również tematykę edukacyjną. Dowodnym przykładem wczesnych aplikacji AT w obszar kształcenia i wychowania może być jeden z pierwszych artykułów na ten temat, poszukujący podobieństw i różnic między pracą nauczyciela i psychoterapeuty oraz rozpoznawania gier interpersonalnych, jakie mają miejsce w klasie szkolnej ${ }^{1}$. Od tego czasu

1 S. Soles, Social Dynamics: A Study of Classroom Games - Progress Report, „Transactional Analysis Bulletin” 1963, t. 2, nr 8, s. 97, za: N. Emmerton, 
problematyka zawodu nauczycielskiego towarzyszy nieprzerwanie szeregu autorom, którzy dostrzegli liczne możliwości interpretacji i rozumienia pracy nauczycielskiej z perspektywy AT. Nauczyciel oraz jego psychologiczne funkcjonowanie osobiste i zawodowe stało się też przedmiotem zarówno zagranicznych, jak i polskich interesujących prac badawczych, które bez przesady określić można wręcz wspólnym mianem pedeutologii AT. Przywołanie owych dokonań, $\mathrm{z}$ reguły mniej znanych $\mathrm{w}$ polskiej pedagogice, stanowi główny cel niniejszego artykułu.

\section{Edukacyjna analiza transakcyjna i jej cele}

Tak jak powiedziano już wcześniej, obecność problematyki nauczycielskiej pojawia się już u zarania powstania oraz kształtowania się koncepcji analizy transakcyjnej. Dalsze prace potwierdzają tylko zainteresowanie badaczy nauczycielem i budowanymi przez niego relacjami z uczniami, a także rodzicami uczniów, oraz rozwiązywaniem trudnych problemów mogących pojawiać się na terenie szkoły. O możliwości wykorzystania założeń analizy transakcyjnej w edukacji pisał już 1971 roku Thomas Frazier, stwierdzając:

Zasady analizy transakcyjnej mogą być użyteczne w praktyce klasy szkolnej. Cele edukacji mogą różnić się od celów psychoterapii; aczkolwiek uczucia nadziei, oczekiwania, frustracje i osiągnięcia są obecne w klasie i dlatego zasady ludzkiego zachowania i dynamiki grupy moga być zastosowane także tutaj².

W kolejnych latach i w późniejszych opracowaniach coraz częściej zaczęto podkreślać znaczenie AT w kontekście zadań edukacyjnych i wychowawczych oraz samej pracy nauczyciela ${ }^{3}$. Podstawowe doktrynalne założenia ${ }^{4}$, będące kanwą edukacyjnej analizy transakcyjnej,

T. Newton, The Journey of Educational Transactional Analysis from Beginnings to the Present, „Transactional Analysis Journal” 2004, t. 34, nr 3, s. 283.

2 T.L. Frazier, The Application of Transactional Analysis Principles in the Classroom of a Correctional School, „Transactional Analysis Journal” 1971, t. 1, nr 4, s. 16.

3 N.E. Amundson, D.D. Sawatzky, An Educational Program and AT, „Transactional Analysis Journal" 1976, t. 2, nr 6, s. 217-220.

4 What Is Transactional Analysis?, https://www.itaaworld.org/what-transactional-analysis [dostęp: 8.02.2017]. 
sprowadzają się do przekonania, że skuteczność wychowawcza wiąże się z empatią i poszanowaniem godności wszystkich osób biorących udział w procesie wychowawczo-dydaktycznym. W szczególny sposób odnosi się to do nauczyciela i pełnionej przez niego roli. Wspomniane cechy budują udane relacje między nauczycielem i uczniem, tworząc optymalny klimat wychowawczy. W przypadkach trudności edukacyjnych, jakie nieuchronnie mogą się pojawiać, ich skuteczne rozwiązywanie może nastąpić tylko wówczas, gdy w przezwyciężenie tych kłopotów zaangażowane są wszystkie strony konfliktu, nie tylko nauczyciel, ale również uczniowie oraz rodzice, a także władze szkolne. Wspomniane osoby muszą mieć dobrą wolę współpracy, posiadać gotowość do poruszania się w spójnych ramach określonych założeń teoretycznych lub czysto zdroworozsądkowych. Powinna im też towarzyszyć gotowość do trafnego rozumienia rzeczywistości oraz samoświadomość osób zaangażowanych w złożone i wieloaspektowe procesy edukacyjne.

Jak twierdzi się w wielu opracowaniach, edukacyjna analiza transakcyjna może się okazać przydatna choćby w rozwiązywaniu problemów związanych z kształceniem i doskonaleniem pracy nauczycieli oraz dostarczaniem wiedzy czy umiejętności pedagogicznych zarówno samym nauczycielom, jak również rodzicom uczniów. Może też pomóc w tworzeniu właściwego klimatu szacunku i kultury psychologicznej szkoły, usprawnianiu procesu uczenia się oraz rozbudzania motywacji do uczenia się. Nie bez znaczenia jest także pomoc w podnoszeniu sprawności organizacyjnej poszczególnych placówek szkolnych i wychowawczych oraz całego sytemu oświaty.

Za szczegółowe cele edukacyjnej analizy transakcyjnej dość powszechnie uważa się stworzenie nowych perspektyw w spojrzeniu na to, jak ludzie w istocie się uczą, oraz co zrobić, aby kształcenie mogło się stać bardziej efektywne. Jest to zatem analiza nowych metod, które aktywizują uczniów, w tym sposobów uczenia się poprzez doświadczenie oraz edukację skoncentrowaną na samym uczniu. To budowanie procesu uczenia się w taki sposób, że jego kierunek w jakimś stopniu wyznacza w przeważającej mierze sam uczeń, a nie represyjny system narzucony z góry. Pojawia się tu również opanowywanie umiejętności radzenia sobie nauczyciela $z$ edukacyjnymi sytuacjami problemowymi. Wymienia się przy okazji dążenie do rozwoju teorii edukacji bez poczucia winy (blade-free theory), która może uczynić 
zarówno nauczanie, jak i uczenie się mniej obciążającym z psychologicznego punktu widzenia dla podmiotów tego procesu ${ }^{5}$.

Powyższe cele mają być realizowane poprzez dwie fundamentalne zasady praktyki nauczycielskiej. Dodajmy w tym miejscu, że są one charakterystyczne zarówno dla psychoterapii, jak również dla praktyki edukacyjnej. Pierwsza z zasad mówi o metodzie kontraktu. Zakłada ona, że relacja między nauczycielem a uczniem powinna się opierać na wspólnie uzgodnionej umowie co do celów uczenia się, stosowanych sposobów działania i efektów, jakie ma to przynieść. Ma to na celu ponoszenie wspólnej odpowiedzialności za uzyskiwane rezultaty. Mówiąc zaś precyzyjniej, chodzi tu o skłonienie ucznia do wzięcia na siebie części odpowiedzialności za edukację, bez obarczania tym wyłącznie nauczyciela. Druga reguła koncentruje się na kwestii otwartej - pozbawionej gier psychologicznych i różnorodnych rodzajów psychomanipulacji - komunikacji interpersonalnej między nauczycielem i uczniem.

W praktyce analizy transakcyjnej powyższe cele i zasady realizuje się najczęściej dzięki programom specjalistycznych szkoleń6 adresowanych do nauczycieli oraz dzieci i młodzieży ${ }^{7}$, a także dzięki wykorzystaniu różnych form pracy z uczniami mającymi trudności w nauce ${ }^{8}$. W ramach tej teorii prowadzi się badania ewaluacyjne programów edukacyjnych i konkretnych form pracy nauczyciela. Publikowane badania interdyscyplinarne analizują instytucję szkoły z punktu widzenia AT, jako strukturę organizacyjną, środowisko kulturowe i miejsce specyficznych interakcji międzyosobowych. Ciekawe rezultaty w zakresie wprowadzania AT do szkół uzyskano w Wielkiej Brytanii, gdzie stwierdzono znaczne podwyższenie efektywności pracy uczniów i nauczycieli dzięki zastosowaniu wspomnianych reguł. Zauważono, że zachęcanie uczniów do przyjęcia zachowań

5 N. Emmerton, T. Newton, The Journey of Educational Transactional Analysis from Beginning to the Present, dz. cyt., s. 289.

6 G. Barrow, E. Bradshaw, T. Newton, Improving Behaviour and Raising Self-Esteem in the Classroom: A Practical Guide to Using Transactional Analysis, London 2001.

7 C. Garrison, R. Fischer, Introducing TA in the Public School System, „Transactional Analysis Journal" 1978, t. 8, nr 3, s. 244-246.

8 M.J. Fine, G. Covell, D.B. Tracy, The Effects of TA Training on Teacher Attitudes and Behavior, „Transactional Analysis Journal” 1978, t. 8, nr 3, s. 236-240. 
z pozycji stanu Ja-Dorosły bywa pierwszym krokiem zapoczątkowującym właściwą postawę wobec nauki i odpowiedzialne podejście do swoich obowiązków. Chcąc promować zasady rozwoju emocjonalnego uczniów, Instytut Rozwoju Analizy Transakcyjnej (IDEA) ustanowił nagrodę dla Dzieci i Młodzieży (TEPACY), która sprzyja budowaniu dobrych relacji w szkole9.

Zaobserwowano również, co potwierdziły badania, że kształcenie samych nauczycieli w zakresie AT skutkuje budowaniem dobrych relacji interpersonalnych w klasie szkolnej. Stąd też oddzielne miejsce $\mathrm{w}$ analizie transakcyjnej zajmuje osoba samego nauczyciela, posługiwanie się przez niego własnymi stanami Ja w relacjach z uczniami ${ }^{10}$, obszar jego ważnych umiejętności przydatnych w radzeniu sobie $\mathrm{z}$ destrukcyjnymi zachowaniami uczniów ${ }^{11}$, a w szczególności zapobieganie prowadzeniu przez niego samego i uczniów negatywnych gier interpersonalnych ${ }^{12}$. Nie bez znaczenia jest również rodzaj udzielanego wsparcia psychologicznego przez nauczycieli ${ }^{13}$. To tylko niektóre z szeregu jeszcze innych kwestii mieszczących się w nabywaniu przez nauczyciela kompetencji zawodowych dzięki szkoleniom w zakresie analizy transakcyjnej.

\section{Edukacyina analiza transakcyjna w Polsce}

Zainteresowanie i rozwój edukacyjnej analizy transakcyjnej w Polsce jest kwestią zaledwie kilku ostatnich lat. Wymienić tu można m.in. znaczące publikacje Doroty Pankowskiej ${ }^{14} \mathrm{z}$ Uniwersytetu

9 G. Barrow, Transactional Analysis, Pastoral Care and Education, „Pastoral Care in Education" 2007, t. 25, nr 1, s. 21-25.

10 W.J. Kenney, Problem-Student Effects on Teacher Ego States Behavior, „Transactional Analysis Journal" 1981, t. 3, nr 11, s. 252-253.

11 G. King, Umiejętności terapeutyczne nauczyciela, przeł. J. Bartosik, Gdańsk 2003, s. 61-62.

12 K. Ernst, Szkolne gry uczniów. Jak sobie z nimi radzic, przeł. J. Troczyński, Warszawa 1991; J. Jagieła, Gry psychologiczne w szkole, Kielce 2004.

13 P. Hough, Teachers and Stroking, „Transactional Analysis Journal” 1971, t. 3, nr 1, s. 38-39.

14 D. Pankowska, Wykorzystanie analizy transakcyjnej w pracy nauczyciela, w: Rozpoznania i szkice pedagogiczne, red. D. Jankowska, Łódź 2005, s. 51-69; D. Pankowska, Stosowanie analizy transakcyjnej w praktyce szkolnej a zdrowie psychiczne, w: Zdrowa szkota - zdrowy uczeń. Edukacja wobec wspótczesnych 
im. Marii Curie-Skłodowskiej w Lublinie. Jednak przełomowe znaczenie dla zaistnienia problematyki EAT w Polsce miała decyzja Senatu Akademii im. Jana Długosza w Częstochowie o powstaniu w maju 2010 roku Zespołu Badawczego Edukacyjnej Analizy Transakcyjnej. Przez okres funkcjonowania tej placówki naukowej, niemającej swojego akademickiego odpowiednika zarówno kraju, jak i za granicą, powstało wiele znaczących publikacji. Trzeba podkreślić, że pierwszą monografią w Polsce poświęconą tej tematyce stała się praca zbiorowa Analiza transakcyjna w teorii i praktyce pedagogicznej (1997). Po niej powstały następne, m.in. Analiza transakcyjna w edukacji (2011), Edukacyjna analiza transakcyjna w kilku odstonach (2012) oraz wiele innych wysoko ocenianych opracowań o charakterze monograficznym, popularnonaukowym czy leksykalnym ${ }^{15}$. Zespół wydaje czasopismo „Edukacyjna Analiza Transakcyjna” oraz opracował szereg monografii w ramach serii wydawniczej: „Biblioteka Edukacyjnej Analizy Transakcyjnej”16. Seria ta jest jedynym jak dotąd periodykiem naukowym poświęconym analizie transakcyjnej w Polsce ${ }^{17}$,

zagrożeń zdrowia, red. A. Grabowiec, A. Bogucki, A. Bochniarz, Lublin 2008, s. 123-134; D. Pankowska, Metodologia analizy transakcyjnej-przegląd badań, „Przegląd Badań Edukacyjnych”2008, nr 1, s. 99-115; D. Pankowska, Nauczyciel w perspektywie analizy transakcyjnej, Lublin 2010; D. Pankowska, Analiza transakcyjna w edukacji, czy edukacyjna analiza transakcyjna? - próba porzadkowania znaczeń, „Edukacyjna Analiza Transakcyjna” 2012, nr 1, s. 13-30 i inne.

15 J. Jagieła, Grypsychologiczne w szkole, dz. cyt.; J. Jagieła, Komunikacja interpersonalna w szkole, Kraków 2004; J. Jagieła, Narcystyczna szkoła. O psychologicznej rzeczywistości szkoty, Kraków 2010; J. Jagieła, Analiza transakcyjna - perspektywy aplikacji pedagogicznych, w: Analiza transakcyjna w teorii $i$ praktyce pedagogicznej, red. J. Jagieła, Częstochowa 1997, s. 17-41; J. Jagieła, Stownik analizy transakcyjnej, Częstochowa 2012 i szereg innych artykułów naukowych i popularnonaukowych $z$ tego zakresu.

16 W ostatnim okresie ukazały się m.in. następujące monografie: J. Jagieła, A. Sarnat-Ciastko, Dlaczego analiza transakcyjna? Rozmowy o zastosowaniu analizy transakcyjnej w pracy nauczyciela $i$ wychowawcy, Częstochowa 2015; J. Jagieła, Edukacyjna Analiza Transakcyjna w kilku odstonach, Częstochowa 2012; D. Gębuś, A. Pierzchała, Twórczy nauczyciele, pomystowi uczniowie. Osobowościowe korelaty kreatywności nauczycieli z perspektywy analizy transakcyjnej, Częstochowa 2016; Z. Łęski, Duch w maszynie... Kim dla nas jest komputer? Charakterystyka zjawiska w języku analizy transakcyjnej, Częstochowa 2016.

17 Zagraniczne czasopisma naukowe poświęcone AT to m.in.: „Transactional Analysis Journal”, ,International Journal of Transactional Analysis Research” oraz „Zeitschrift für Transaktionsanalyse”. 
a w wydaniu edukacyjnym nie posiada też swojego zagranicznego odpowiednika. Na łamach tego periodyku swoje artykuły publikowali nie tylko polscy autorzy, ale także znani badacze problematyki EAT z Wielkiej Brytanii ${ }^{18}$, Austrii1 ${ }^{19}$ oraz Ukrainy. Autorzy publikowanych opracowań zaprezentowali w niej np. możliwości identyfikacji skryptu somatycznego danej osoby na podstawie ulubionej dziecięcej bajki ${ }^{20}$.

Członkowie Zespołu mogą się poszczycić wypracowaniem własnych modeli teoretycznych oraz metod i narzędzi badawczych, a także uzyskiwaniem kolejnych stopni naukowych. Ich dorobek naukowy pozwala już w obecnej chwili na uzyskanie w niedalekiej przyszłości stopni doktora habilitowanego w zakresie pedagogiki. Dwie dysertacje doktorskie dotyczące edukacyjnej analizy transakcyjnej uzyskały wyróżnienia rad wydziału ${ }^{21}$. Ponadto jedna $\mathrm{z}$ tych prac uzyskała główną nagrodę Kapituły II Konkursu na najlepszą pracę doktorską w dziedzinie diagnozy edukacyjnej przyznawaną przez Zarząd Główny Polskiego Towarzystwa Diagnozy Edukacyjnej ${ }^{22}$. Przygotowywane są kolejne prace doktorskie $z$ tej tematyki, czekają one na swoją szczęśliwą finalizację $e^{23}$.Zespół uzyskał też nagrodę pierwszego actional Analysis: A Personal Encounter, „Edukacyjna Analiza Transakcyjna” 2016, nr 5, s. 29-37, http://dx.doi.org/10.16926/eat.2016.05.02.

S. Schachner, Models of Transactional Analysis in Educational Management „Edukacyjna Analiza Transakcyjna” 2016, nr 5, s. 35-49, http://dx.doi. org/10.16926/eat.2016.05.03.

20 K. Bulhakova, Z. Sevalneva, Rabota s telesnym scenariem spomoŝ'û lûbimoj detskoj skazki, „Edukacyjna Analiza Transakcyjna” 2015, nr 4, s. 36-44, http:// dx.doi.org/10.16926/eat.2015.04.02.

21 A. Pierzchała, Pasywnośc szkolna w analizie transakcyjnej. Studium relacji nauczyciele z uczniem (Wydział Pedagogiczny, Katedra Psychopedagogiki, Akademia Ignatianum w Krakowie, 2013); A. Sarnat-Ciastko, Tutoring w polskim systemie oświaty. Badania nad rozwojem metody tutoringu ze szczególnym uwzględnieniem efektów jej stosowania dla nauczyciela i ucznia w ujęciu analizy transakcyjnej,(Wydział Pedagogiczny, Katedra Psychopedagogiki, Akademia Ignatianum Krakowie, 2014).

22 A. Sarnat-Ciastko, Tutoring w polskim systemie oświaty. Badania nad rozwojem metody tutoringu ze szczególnym uwzględnieniem efektów jej stosowania dla nauczyciela i ucznia w ujęciu analizy transakcyjnej, (Wydział Pedagogiczny, Katedra Psychopedagogiki, Akademia Ignatianum Krakowie, 2014).

23 K. Motyl, Temporalny wymiar życia szkoty. Transakcyjne formy strukturalizacji czasu uczniów, (Instytut Nauk o Wychowaniu, Akademia Ignatianum 
stopnia J.M. Rektora Akademii im. Jana Długosza w Częstochowie za osiągnięcia naukowe w roku 2017.

Kolejne prace badawcze ZBEAT finansowane były z przyznanych grantów uczelnianych. W latach 2016-2018 członkowie Zespołu włączyli się w badania nad realizacją programem „Wychować człowieka mądrego. Wprowadzenie modelu pracy wychowawczej i resocjalizacyjnej z zastosowaniem metody tutoringu szkolnego jako profilaktyki pozytywnej problemów w polskiej szkole", finansowanego ze środków Ministerstwa Edukacji Narodowej ${ }^{24}$. Znaczącym osiągnięciem Zespołu stała się też realizacja międzynarodowego projektu badawczego zatwierdzonego przez polskie Ministerstwo Nauki i Szkolnictwa Wyższego oraz Ministerstwo Szkolnictwa Wyższego Ukrainy.

Projekt realizowany przez ZBEAT oraz pracowników naukowych Katedry Psychologii Rozwojowej i Pedagogicznej Rówieńskiego Państwowego Uniwersytetu Humanistycznego ma być realizowany w latach 2017-2019. Przedmiotem projektu jest analiza komparatystyczna przekazu wartości u młodzieży polskiej i ukraińskiej: „System wartości i transakcyjne elementy skryptowe (life script) ukraińskiej i polskiej młodzieży akademickiej" (The value systems and life scripts of Polish and Ukrainian university students a comparative analysis based on the concept of transactional analysis). Realizacja projektu obliczonego na kilka etapów zaowocowała już cenną wymianą doświadczeń między stroną polską i ukraińską oraz odbytymi stażami naukowymi.

Tak jak wspomniano, analiza transakcyjna znalazła dość szybko zastosowanie jako jedna z form szkolenia nauczycieli w celu podniesienia ich kompetencji, samoświadomości oraz rozwoju osobistego i zawodowego. Maria Ryś, jedna z czołowych przedstawicielek polskiej psychologii i pedagogiki, pisze następująco: „Zastosowanie analizy transakcyjnej pozwala osiągnąć zdolność kształtowania własnego życia bez negatywnych wpływów przeszłości, dzięki uwolnieniu się od wadliwych zapisów w scenariuszach życiowych

w Krakowie); W. Świątek, Przemoc w szkole. Charakterystyka zjawiska z punktu widzenia edukacyjnej analizy transakcyjnej, (Instytut Nauk o Wychowaniu, Akademia Ignatianum w Krakowie).

24 Realizator projektu: Towarzystwo Edukacji Otwartej - organ prowadzący dla Instytutu Tutoringu Szkolnego. 
oraz dzięki ćwiczeniu się w dorosłych relacjach" 25 . Wspomniany walor edukacyjnej analizy transakcyjnej $\mathrm{w}$ przygotowaniu zawodowym nauczycieli oraz wychowawców dostrzegły Sylvia Schachner i Susannah Temple, dwie czołowe przedstawicielki tego nurtu na świecie.

\section{Praca nauczyciela według Sylvii Schachner}

Sylvia Schachner w jednym ze swoich artykułów ${ }^{26}$ wskazuje na zidentyfikowane przez siebie wzorce mające służyć stworzeniu korzystnych warunków nauczania i pracy nauczyciela. „Modele te są pomocne do opisania obserwowanych procesów oraz widocznych efektów podejmowanych transakcji i interwencji" ${ }^{27}$ - pisze autorka. Pierwszy ze schematów zniewalający swoją prostotą, ale też niebudzącą wątpliwości pedagogiczną trafnością, powstał w oparciu o wyodrębnione przez Erica Berne'a podstawowe potrzeby (nazywane też w AT „głodami” (ang. hunger). Powstają one na wczesnych etapach rozwojowych dziecka na poziomie biologicznym, później są formowane i symbolizowane również w obszarze psychiki. Wyodrębniono w ten sposób: głód stymulacji (stimulus hunger), głód wsparcia (recognition hunger) oraz głód strukturalizacji czasu (bunger for time structure $)^{28}$. Potrzeby te stały się kanwą, na jakiej za pomocą trójkąta równobocznego autorka ukazała trzy wspierające się wzajemnie elementy procesu dydaktycznego i wychowawczego szkoły oraz kierunki, jakimi powinien podążać nauczyciel, aby uzyskać równowagę i harmonię w swojej pracy dydaktycznej, zaspokajając w ten sposób naturalne potrzeby ucznia. Uczeń musi zatem otrzymywać od swojego nauczyciela wsparcie w swoich zmaganiach i trudnościach w opanowywaniu wiedzy oraz w zdobywaniu koniecznych umiejętności. Jest to szczególnie ważne wtedy, gdy uczeń napotka na określone trudności w uczeniu się.

M. Ryś, Konflikty w rodzinie, Warszawa 1998, s. 5.

S. Schachner, Models of Transactional Analysis, dz. cyt., s. 35-49.

Tamże, s. 40.

E. Berne, Dzień dobry... i co dalej? Psychologia ludzkiego przeznaczenia, przeł. M. Karpiński, Poznań 1998, s. 40-41. 
W koncepcji analizy transakcyjnej tego rodzaju wsparcie otrzymuje się dzięki jednostce interpersonalnego uznania, którą nazywa się również tzw. znakiem zauważenia ${ }^{29}$.

W niektórych tłumaczeniach opatrywana jest też rzeczownikiem odczasownikowym i nazywana „głaskiem”, co ma obrazować w sposób dosłowny podobieństwo do głaskania po głowie małego dziecka na wczesnych etapach jego rozwoju, a później jest symbolizowane w trakcie rozwoju za pomocą słów (np. pochwał, wyróżnień czy afirmacji). Stymulacja taka ma pobudzać do spontanicznych poszukiwań, działania i kreatywności, będąc w ten sposób zaprzeczeniem biernej recepcji treści i pasywnej obecności w szkole. Z kolei jasna struktura organizacyjna lekcji, którą ma tworzyć przede wszystkim nauczyciel, zmierza do uzyskania poczucia bezpieczeństwa przez ucznia i utrzymania porządku w przebiegu lekcji. W konsekwencji: „Z pomocą tego trójkąta jest możliwe zaplanowanie jednostek dydaktycznych w sposób zrównoważony. Jeżeli pojawiają się zaburzenia tego procesu, to model ten pozwala znaleźć pojawiające się problemy i podjąć skuteczne interwencje" - pisze Schachner ${ }^{30}$. Autorka na prowadzonych przez siebie warsztatach dla nauczycieli ukazuje praktyczne sposoby posługiwania się wspomnianym modelem ${ }^{31}$.

Analiza transakcyjna nie ogranicza się jednak wyłącznie do wskazania nauczycielowi jedynego możliwego modelu, według którego ma on budować swoje optymalne relacje z uczniami. Inne z rozwiązań nawiązuje do modelu określanego w AT jako „Model 3P” (The Three P's Model). Są to zasady, zaproponowane już na wczesnym etapie powstawania samej koncepcji ${ }^{32}$, określające zakres oddziaływań terapeutycznych, ale odnoszące się - jak twierdzi Schachner - w równym stopniu do pracy nauczyciela. Również i te elementy układają

29 Ang. stroke - tłumaczone na język polski jako: stroki, strouki, głaski, wzmocnienia, znaki rozpoznania, znaki uznania, aprobata, por. J. Jagieła, Stownik analizy transakcyjnej, dz. cyt., s. 210-213.

30 S. Schachner, Models of Transactional Analysis, dz. cyt., s. 40.

31 Autor miał możliwość uczestnictwa w prowadzonym przez dr Sylvię Schachner PTSTA-E warsztacie edukacyjnej analizy transakcyjnej „Różne style uczenia się oraz metody związane $z$ analizą transakcyjną”, Polskie Towarzystwo Integratywnej Analizy Transakcyjnej, Kraków 7-8 lutego 2015 r.

32 P. Crossman, Permission and Protection, „Transactional Analysis Bulletin” 1966, nr 5, s. 152. 
się w równoboczny trójkąt i wyznaczają reguły, według których ma postępować nauczyciel i wychowawca. W konsekwencji sprowadzają się do udzielania pozwoleń, ochrony oraz posiadania przez nauczyciela wewnętrznej mocy czy siły.

Pozwolenie (Permission) - wyraża zgodę na odrzucenie przez klienta zachowań, które chce on wyeliminować ze swojego zachowania. W przypadku odniesień do sytuacji szkolnych Schachner pisze o tym następująco:

Uczniowie przychodzą do szkoły ze swoimi osobistymi przekazanymi im nakazami i przekonaniami skryptowymi. Pozwolenie na to, aby myśleć, odkrywać, zgoda, aby spróbować czegoś nowego, są niezbędnymi czynnikami dobrego procesu uczenia się ${ }^{33}$.

Ochrona (Protection) - to nic innego jak asekuracja danej osoby przed skutkami złamania utrwalonych i dysfunkcjonalnych wewnętrznych zakazów. Schachner komentuje to w kontekście szkoły w następujący sposób:

W odniesieniu do ciągłości procesu uczenia się jest niezwykle ważne, aby istniała przestrzeń, w której uczniowie mogą w bezpieczny sposób odkrywać swoje zdolności społeczne i intelektualne. Nauczyciel jest odpowiedzialny za przestrzeganie w klasie reguł negocjacji, a nie przemocy ${ }^{34}$.

Autorka uznaje tę regułę za najważniejszy element omawianej triady odnoszącej się do pracy nauczyciela.

Siła, moc (Power, Puissance, Potency) - to doświadczanie przez klienta energii potrzebnej do konfrontacji ze swoimi problemami, płynącej ze strony terapeuty lub grupy terapeutycznej. W przypadku zaś szkoły:

Siła działania nauczyciela to jego zdolności do nauczania. On lub ona musi mieć głęboką wiedzę na temat procesów uczenia się, znać możliwości i ograniczenia metod dydaktycznych oraz metod przyczyniających się do rozwoju. Znać potrzeby uczniów i studentów. Wszystko to daje możliwość uczniom doświadczenia poczucia własnej skuteczności i znajdowania swoich własnych strategii uczenia się, a także rozwijania zainteresowań ${ }^{35}$.

33 S. Schachner, Models of Transactional Analysis, dz. cyt., s. 41.

34 Tamże, s. 41.

35 Tamże. 
Wymieńmy jeszcze jeden z modeli AT wskazany przez Sylvię Schachner jako wiążący się z problematyką edukacyjną i pracą samego nauczyciela, a dotyczący wyodrębnionych w tej teorii tzw. pozycji życiowych (life position). Są to fundamentalne przekonania danej osoby o sobie i innych ludziach, które zostały uformowane na najwcześniejszych etapach rozwoju. Jest to swoiste okno na świat, przez które ktoś patrzy na siebie i na innych, przestrzega określonych wartości w sobie oraz w otoczeniu, a także często usprawiedliwia w ten sposób swoje decyzje, zachowania lub zaniechania ${ }^{36}$.

Wyodrębnione cztery postawy życiowe, określane też czasem jako pozycje egzystencjalne, psychologiczne, bazowe lub transakcyjne, mają zatem również kolosalne znaczenie w przypadku postawy nauczyciela, jego zachowania i stosunku do swojej pracy, w tym relacji wobec uczniów, rodziców oraz kolegów i koleżanek czy władz oświatowych.

Pozycja: „Ja nie jestem OK - Wy (Ty) jesteście OK $(-,+$ )" - nauczyciel sytuuje siebie w pozycji gorszej od innych, stąd przez klinicystów taka postawa określana bywa jako neurotyczna i wynikająca z niskiej samooceny.

Nauczyciele tacy - jak pisze Schachner - w pierwszej chwili wydają się być bardzo zaangażowani. Są bardzo zainteresowani dobrem uczniów, mają dużo materiałów do nauki i są skłonni wiele im wyjaśniać. Bardzo często mają problemy, by określić granice, limity, i to uzasadnić. Czasami nie czują się dobrze w roli zawodowej. Chcieliby czegoś więcej, starają się, aby być przyjacielem uczniów i kimś niezastąpionym ${ }^{37}$.

Pozycja: „Ja nie jestem OK - Wy (Ty) nie jesteście OK (-, -)”nauczyciel określa siebie, jak również innych, w sposób negatywny, dlatego też taka postawa bywa nazywana udaremniającą, a skrajnych przypadkach świadczyć może również o depresji lub schizoidalnych zaburzeniach osobowości.

Nauczyciele tacy są sfrustrowani i nieskłonni do jakichkolwiek zmian $\mathrm{w}$ swojej pracy w szkole. Brakuje im często uznania i nie widzą sensu swojego działania. Albo też są wypaleni, czy nie dostrzegają żadnego

J.G. Allen, Existential Position and Adjustment in a College Population, „Transactional Analysis Journal” 1973, t. 3, nr 4, s. 22-24; J.G. Allen, D. Webb, Stroking, Existential Position and Mood in College Students, „Transactional Analysis Journal" 1975, t. 5, nr 3, s. 227-233.

37 S. Schachner, Models of Transactional Analysis, dz. cyt., s. 42. 
interesu w wykonywaniu tego rodzaju pracy. Nie należy się spodziewać od nich jakiejkolwiek motywacji lub chęci do nauczania. Sukcesy uczniów nie motywują ich do wysiłku. Nauczycielom tym nie podobają się jakiekolwiek zmiany w systemie pracy szkoły i nie chcą dostosować swoich metod do aktualnej rzeczywistości ${ }^{38}$.

Pozycja: „Ja jestem OK - Wy (Ty) nie jesteście OK (+, -)” - nauczyciel definiuje siebie jako osobę stojącą wyżej od innych. Jest to postawa określająca najlepiej osoby o narcystycznych lub psychopatycznych cechach osobowości.

Nauczyciel występujący w takiej pozycji życiowej działa autorytarnie. Uczniowie muszą się dostosować do niego i treści nauczania. Jeśli tak nie jest, to jest w stanie twierdzić, że jest to ich własna wina, a nie jego samego. Uczniowie muszą wtedy uzyskiwać wiedzę od kogoś innego na zewnątrz szkoły (przykładem mogą tu być korepetycje). Tacy nauczyciele żywią przekonanie, że dzieci nie są wystarczająco przygotowane do szkoły, rodzice nie angażują się w życie szkoły, za mało wspierając swoje dzieci ${ }^{39}$.

Jest to ze wszech miar niepożądana pozycja. Niesie ze sobą wiele niekorzystnych zjawisk, o jakich przeczytać można w książce Narcystyczna szkota. O psychologicznej rzeczywistości szkoty ${ }^{40}$.

Pozycja: „Ja jestem OK - Wy (Ty) jesteście OK (+, +)” - nauczyciel określa siebie i innych w pozytywny sposób. Stąd też nazywana jest postawą właściwą, pożądaną, wartościową i psychologicznie zdrową. Nieprzypadkowo zatem cytowana przez nas autorka tworzy korzystny opis tak funkcjonującego w szkole nauczyciela:

Nauczyciele występujący w tej pozycji życiowej są zainteresowani w wykonywaniu swojego zawodu oraz swoimi uczniami. Są zainteresowani samodoskonaleniem siebie samych i rozwojem swoich uczniów. Widzą w nich osoby o pewnych specyficznych potrzebach edukacyjnych i poszukują metod stymulujących proces uczenia się. Doskonalą swoje własne zdolności i dostosowują swoje metody oraz materiały do nauki i rzeczywistych potrzeb uczniów. Są pewni siebie w kierowaniu pracą w klasie i rozwiązywaniu trudnych sytuacji edukacyjnych. Mają zaufanie do swoich uczniów i wspierają ich w taki sposób, aby nabyli przekonania, że nauczanie może być skuteczne, a uczniowie są w stanie osiągnąć cele uczenia się ${ }^{41}$.

Tamże.

Tamże.

J. Jagieła, Narcystyczna szkota. O psychologicznej rzeczywistości szkoty, dz. cyt. S. Schachner, Models of Transactional Analysis, dz. cyt., s. 42. 
Taki model funkcjonowania nauczyciela jawi się zatem jako najbardziej oczekiwany z punktu widzenia edukacyjnej analizy transakcyjnej. Wydaje się jednak, że zaprezentowana typologia, choć posiada swój niewątpliwy walor, to jednak wymaga bardziej pogłębionej analizy psychologicznej na podstawie prowadzonych badań empirycznych.

\section{Płynność funkcjonalna nauczyciela w ujęciu Susannah Temple}

Wskazując na modele odnoszące się do osoby nauczyciela w edukacyjnej analizie transakcyjnej, nie można pominąć propozycji jaka powiła się wraz z koncepcją płynności funkcjonalnej (functional fuency - FF), opracowanej przez Susannah Temple ${ }^{42}$. Przełomowe znaczenie dla wypracowania całej koncepcji miał jej artykuł, który ukazał się w „Transactional Analysis Journal” w 1999 roku, a który był wprost adresowany do edukacyjnych analityków transakcyjnych i podkreślał doniosłość nowych rozwiązań dla teorii i praktyki pedagogicznej ${ }^{43}$. Rozwiązania te dotyczyły w przeważającej mierze

S. Temple, Functional Fluency for Educational Transactional Analysts, „Transactional Analysis Journal" 1999, t. 29, nr 3, s. 164-174; S. Temple, The Development of a Transactional Analysis Psychometric Tool for Enhancing Functional Fluency, (nieopublikowana rozprawa doktorska - University of Plymouth, 2002); S. Temple, Functional Fluency, „Zeitschrift für Transaktionsanalyse” 2002, nr 4, s. 251-269; S. Temple, Action on the Functional Model, „EATA Newsletter" 2003, nr 76, s. 4-8; S. Temple, Building Self-awareness, 2004, https://westtownapps.com/modx2/section-a/ [dostęp: 7.01.2017]; S. Temple, Update on the Functional Fluency Model in Education, "Transactional Analysis Journal" 2004, t. 34, nr 3, s. 197-204; S. Temple, Bringing Up the Child: The Importance of Functionally Fluent Parents, Carers and Educators, w: The Adults Is Parent to the Child: TA with Children E Young People, red. K. Tudor, Lyme Regis 2008, https://westtownapps.com/modx2/section-a/ [dostęp: 7.01.2017]; S. Temple, Mentors, Coaches and the Empowerment Factor: Why Functional Fluency is Important, 2009, https://westtownapps. com/modx2/section-a/ [dostęp: 7.01.2017]; S. Temple, TIFF 10 Years On: Life Cycle of a Research Project, "The Transactional Analyst” 2012, t. 4, nr 2, s. 3-17; S. Temple, Mastering "The Tolstoy Effect": A Research Exercise in Linguistic Philosophy, 2012, https://westtownapps.com/modx2/section-a/ [dostęp: 7.01.2017]; S. Temple, Celebrating Functional Fluency and Its Contribution to Transactional Analysis Theory, "Transactional Analysis Journal” 2015, t. 45, nr 1, s. 10-22, doi:10.1177/0362153714568803.

43 Wcześniejsza wersja tego artykułu zatytułowanego Jak zostać edukatorem AT została opublikowana w roku 1998 na Uniwersytecie Jyväskylä w Finlandii. 
rozdzielenia modelu strukturalnego osobowości od modelu funkcjonalnego. Edukacyjny analityk transakcyjny - twierdzi Sylvia Schachner - ma z pomocą nauczyciela zaoferować uczniom poczucie siły, ochronę i pozwolenie w dochodzeniu do autonomii. Klasa szkolna powinna się stać bezpiecznym miejscem, gdzie można nawiązywać przyjaźnie i czuć się dobrze. Aby jednak tak się stało, wychowawca i nauczyciel muszą rozwijać swoją świadomość, spontaniczność i zdolność do poszanowania intymności, po to, aby zmniejszyć prawdopodobieństwo inicjowania niekorzystnych transakcji (np. symbiotycznych, zakwestionowanych, deprecjonujących itd.). Powinien natomiast zwiększyć zdolność do reagowania w sposób elastyczny i skuteczny, wykorzystując w tym celu różne stany swojego $\mathrm{Ja}^{44}$.

Wymowa modelu FF, inspiracja do jego powstania i kolejne jego przybliżenia zostały szeroko zaprezentowane oraz omówione na jednej z plenarnych sesji pierwszej konferencji internetowej poświęconej edukacyjnej analizie transakcyjnej ${ }^{45}$. Nie pozostaje zatem nic innego, jak odesłanie Czytelnika do tego wystąpienia, które w całości zostanie najpewniej opublikowane w kolejnym numerze „Edukacyjnej Analizy Transakcyjnej”. W tym miejscu jedynie skrótowo zostaną przedstawione najistotniejsze elementy wspomnianego modelu.

Najogólniej można zatem powiedzieć, że zaproponowane przez Susannah Temple rozwiązania zainspirowane zostały schematem R-D-Dz (Rodzic-Dorosły-Dziecko) stanów Ja Erica Berne’a. Nie są one jednak z tym podstawowym dla AT modelem tożsame. Temple pisze:

Trzeba pamiętać, że funkcjonalny model płynności nie jest modelem stanów ego jakiegokolwiek rodzaju. Jak odkryto w trakcie procesu badawczego, stanowi on oddzielny model ludzkiego funkcjonowania społecznego $\mathrm{z}$ własną terminologią ${ }^{46}$.

S. Temple, Functional Fluency for Educational Transactional Analysts, dz. cyt., s. 164.

45 J. Jagieła, Znaczenie modelu ptynności funkcjonalnej (FF - functional fluency) Susannah Temple dla rozwoju osobistego $i$ zawodowego nauczycieli z perspektywy edukacyjnej analizy transakcyjnej, Konferencja Internetowa „Edukacja - Analiza - Transakcje”, Akademia im. J. Długosza w Częstochowie, 25.05.2017 r.

46 S. Temple, Celebrating Functional Fluency and Its Contribution to Transactional Analysis Theory, dz. cyt., s. 12. 
Istotą propozycji autorki - jak już wspomniano - jest rozdzielenie modelu strukturalnego stanów Ja od funkcjonalnego i skoncentrowanie się na tzw. Zintegrowanym Dorosłym, który jest wyrazem dojrzałej i dobrze funkcjonującej osobowości. Nie trzeba chyba nikogo z pedagogów przekonywać jak istotny jest to cel zabiegów wychowawczych. Posiada on również doniosłe znaczenie w kontekście funkcjonowania i pracy samego nauczyciela. Temple przyjęła, że nauczyciel z pozycji swoich stanów Rodzica lub Dziecka reaguje zazwyczaj odruchowo i impulsywnie. Dopiero Dorosły buduje adekwatną i aktualną odpowiedź na rzeczywistość. Ma to kolosalną wartość dla dobrego funkcjonowania osobistego i zawodowego nauczyciela, który w ten sposób może podejmować decyzje, jest w dobrym kontakcie z uczniami i otoczeniem, ale też z samym sobą. Potrafi również wykorzystać posiadany potencjał adekwatnie do własnego wieku oraz zgromadzonych doświadczeń. Jest to fundamentalna różnica, którą należy zauważyć. „Używam słowa «reaguje» i «odpowiada» - pisze Temple - aby w sensie technicznym podkreślić zasadniczą różnicę między Rodzicem i Dzieckiem a stanem osobowości Dorosłego" ${ }^{37}$. W ten sposób autorka dociera do modelu płynności funkcjonalnej (FF), które to nowe w AT pojęcie określa się jako behawioralną manifestację zintegrowanego i dobrze funkcjonującego stanu Ja-Dorosły. Kształtowanie i rozwój owej dyspozycji nauczyciela ma posłużyć zwiększeniu jego samoświadomości zarówno w wymiarze osobistym, jak i zawodowym ${ }^{48}$.

Aby dobrze zrozumieć ten model i samą płynność funkcjonalną, ważne jest uświadomienie sobie - twierdzi Temple - że nie chodzi tutaj niejako o zmianę samej osoby, ale właśnie o zmianę jej funkcjonowania, czyli usprawnienie interakcji, $w$ jakie wchodzi z innymi. Tego rodzaju płynne funkcjonowanie można w szczególności odnieść do pracy nauczycieli i wychowawców, gdyż umożliwia ono korzystanie z odpowiednich, pozytywnych trybów (oznaczają one tutaj nic innego jak zachowanie), polegających na efektywnym strukturalizowaniu sytuacji szkolnych, zapewnieniu odpowiedniej opieki podopiecznym,

S. Temple, Functional Fluency for Educational Transactional Analysts, dz. cyt., s. 166.

J. Jagieła, Samoświadomośc nauczycieli w koncepcjach edukacyjnej analizy transakcyjnej, „Prace Naukowe Akademii im.Jana Długosza w Częstochowie. Pedagogika"2017,t. 26, nr1,s.69-83,http://dx.doi.org/10.16926/p.2017.26.06. 
umiejętności współpracy oraz bycia osobą spontaniczną w podejmowanych działaniach. Jednocześnie chodzi o posiadanie przez daną osobę kontroli - dzięki możliwości kalkulacji - nad trybami, które mogą mieć w sensie pedagogicznym swoje negatywne konotacje, takie, jak np. przesadna dominacja połączona $\mathrm{z}$ apodyktycznością bądź nadmierną karnością czy nastawieniem na poszukiwanie wyłącznie błędów uczniów. Nieadekwatnymi przejawami opieki jest też pobłażliwość, niekonsekwencja i niespójność zachowań, a także $\mathrm{z}$ jednej strony pewien rodzaj uległości, z drugiej zaś buntu, co tworzy kontinuum między zależnością a oporem. Negatywne aspekty wyżej wymienionych trybów mogą też się wyrażać egocentryzmem lub lekkomyślnością jako przejawami niedojrzałości emocjonalnej. Zintegrowana osobowość oznacza skalkulowanie i wykorzystanie pełnej zdolności do oceny oraz refleksji nad danymi okolicznościami i wszystkimi istotnymi cechami danej sytuacji. To również użycie własnej energii zastosowanej w odniesieniu do innych osób, wyrażające się ciepłem, bezpośredniością, otwartością i gotowością do wyrażania własnej niepowtarzalności oraz indywidualnej kreatywności.

Model ten - jak powiedziano już wcześniej - nie koncentruje się nadmiernie na samej osobie, ale na jej zachowaniu. Dotyczy zasadniczo naturalnego sposobu, w jaki ludzie pozytywnie odnoszą się do siebie. Dana osoba jest biegła (płynna - tego terminu będziemy używać zamiennie) funkcjonalnie, gdy zachowuje się celowo, elastycznie, potrafi wspólpracować z innymi, odnosząc dla siebie oraz swego otoczenia różnego rodzaju korzyści. Słowo płynność oznacza tu sprawność, umiejętność i właśnie biegłość. Natomiast termin „funkcjonalność” odnosi się do funkcjonowania społecznego, co jest w sumie czymś więcej, niż tylko samym zachowaniem. Jest to też wzięcie odpowiedzialności za siebie, ale również za innych w sytuacjach wzajemnej relacji. Oznacza w takich momentach zdolność do pełnej oceny i refleksji, z uwzględnieniem wszystkich istotnych czynników i okoliczności danej sytuacji. To skuteczne wykorzystanie własnej energii w relacji z innymi ludźmi dzięki ciepłu, serdeczności, otwartości i gotowości do wyrażania własnej indywidualności, niepowtarzalności czy kreatywności. Funkcjonalna płynność służy ostatecznie rozwojowi, efektywności i satysfakcji nauczyciela w momentach, gdy pojawia się frustracja, a nawet stres, pomaga takie zdarzenia przetrwać w sposób zadawalający. 
Wspomniany model Susannah Temple wykorzystuje w szkoleniach dla nauczycieli w celu podniesienia ich samoświadomości. Skłoniło to autorkę do opracowania narzędzia służącego do oceny płynności funkcjonalnej pod nazwą: Indeks Płynności Funkcjonalnej Temple (ang. The Temple Index of Functional Fluency-TIFF). Jest to 108-pozycyjny kwestionariusz, dostępny też w wersji online ${ }^{49}$. Każdy profil TIFF jest unikatowy i może stanowić podstawę do prowadzenia rozmów między osobą badaną a analitykiem transakcyjnym. Jest to narzędzie mające na celu zwiększenie zaangażowania i motywacji do zmiany swoich dysfunkcjonalnych zachowań. Jest wspólną eksploracją znaczeń, w której obie strony dzielą się swoją wiedzą. Sprzężeniem zwrotnym w tym procesie jest wzajemne zaangażowanie. Model płynności funkcjonalnej stanowi wzorzec społecznego zaangażowania nauczyciela, a uzyskany w TIFF unikatowy profil jest $\mathrm{z}$ kolei układem odniesienia oświetlającym niejako określone zachowania. Praktyczne wykorzystanie TIFF może mieć przełomowe znaczenie w szkoleniu zarówno kandydatów na nauczycieli i wychowawców, jak i samych praktykujących nauczycieli.

\section{Wnioski}

W artykule przytoczono i omówiono zalewie dwa typowe modele odnoszące się do funkcjonowania w roli zawodowej nauczyciela. W sposób oczywisty nie wyczerpują one całości rozwiązań i poszukiwań, jakie odnaleźć można w obrębie edukacyjnej analizy transakcyjnej, poszukującej specyfiki tego pod wieloma względami wyjątkowego zawodu. Ich przywołanie miało na celu zapoznanie polskiego czytelnika z przykładami tego rodzaju rozwiązań. Tworzą one wyodrębniony nurt refleksji w obszarze EAT, który opatrzono tu mianem pedeutologii analizy transakcyjnej.

Trzeba jednak zauważyć i docenić, że również polscy autorzy podejmują podobne starania. Na szczególną uwagę zasługuje monografia Doroty Pankowskiej. Autorka w konkluzji swojego opracowania w znamienny sposób pisze: al Analysis Theory, dz. cyt. 
Propozycja włączenia analizy transakcyjnej do programów edukacji nauczycielskiej nie ma na celu zastąpienia dotychczasowych treści psychopedagogicznych. Nie jest też pomysłem na wprowadzenie jej do kształcenia nauczycieli jako „najlepszej” czy ,jedynie słusznej” teorii, przed czym przestrzega Dorota Klus-Stańska ${ }^{50}$.

Można przypuszczać, że słowa te skierowane były do tych wszystkich przedstawicieli nauk o wychowaniu, którzy z obawą oraz dystansem odnoszą się do nowych teorii i propozycji wyrastających spoza dotychczasowych oraz utrwalonych schematów myślenia na ten temat. Pankowska dalej pisze $z$ nadzieją, ale też powątpiewaniem: „Aplikowanie analizy transakcyjnej do programu kształcenia (i doskonalenia) nauczycieli możliwe jest zatem w różnych zakresach, choć niektóre z tych rozwiązań w obecnych warunkach nie wydają się realne" ${ }^{51}$. I choć trudno zaprzeczyć tym słowom, to jednak pozostając z głębokim przekonaniem, że rzeczywistość da się zmieniać, a ziemię „czynić poddaną”, należy zauważyć, że pojawiają się liczne zwiastuny świadczące o istniejących możliwościach w tym zakresie ${ }^{52}$.

Badania na temat zawodu nauczyciela były też prowadzone od początku istnienia Zespołu Badawczego Edukacyjnej Analizy Transakcyjnej. Jednak ich zakres i charakter nie pozwalają na formułowanie daleko idących uogólnień. Nie układają się też w jedną myśl przewodnią. Wśród kilkudziesięciu opracowań na ten temat warto wymienić m.in. tekst Jolanty Rogulskiej Cechy nauczyciela wygrywajacego, przegrywajacego $i$ niewygrywającego w sivietle analizy transakcyjnej ${ }^{53}$. Tematyce pedeutologicznej poświęciły też swoje opracowania osoby współpracujące z Zespołem, m.in.: Bożena Uścińska (Nauczycielskie okopy Świętej Trójcy) ${ }^{54}$, Małgorzata Lubańska (Czy analiza transakcyjna może stać się pomocnym "narzędziem” w pracy cyjna” na kilku kierunkach Wydziału Pedagogicznego Akademii im. Jana Długosza w Częstochowie oraz organizację szeregu szkoleń i warsztatów dla nauczycieli prowadzonych przez członków Zespołu Badawczego EAT tej uczelni.

53 J. Rogulska, Cechy nauczyciela wygrywającego, przegrywajacego i niewygrywającego w świetle analizy transakcyjnej, w: Analiza transakcyjna w teorii i praktyce pedagogicznej, red. J. Jagieła, Częstochowa 1997, s. 157-158.

54 B. Uścińska, Nauczycielskie okopy Śrwiętej Trójcy, „Edukacyjna Analiza Transakcyjna" 2012, nr 1, s. 67-76. 
nauczyciela?) ${ }^{55}$, Jolanta Górnik (Nauczyciel widziany oczami gimnazjalisty. Wybrane aspekty funkcjonowania nauczycieli gimnazjum w świetle badań wtasnych) ${ }^{56}$ oraz Zbigniew Eęski (Osobowość nauczyciela w śrwietle analizy transakcyjnej) ${ }^{57}$. Śledząc zakres i charakter polskich publikacji dotyczących nauczyciela na gruncie AT, można mieć nadzieję, że znajdą one swoje kontynuacje w dalszych poszukiwaniach badawczych, odnajdując w ten sposób swoje miejsce jako jeden $z$ dostrzegalnych nurtów polskiej psychopedagogiki i pedeutologii.

\section{Bibliografia}

Allen J.G., Existential Position and Adjustment in a College Population, „Transactional Analysis Journal” 1973, t. 3, nr 4, s. 22-24.

Allen J.G., Webb D., Stroking, Existential Position and Mood in College Students, ,Transactional Analysis Journal” 1975, t. 5, nr 3, s. 227-233.

Amundson N.E., Sawatzky D.D., An Educational Program and AT, „Transactional Analysis Journal" 1976, t. 2, nr 6, s. 217-220.

Barrow G., Transactional Analysis, Pastoral Care and Education, „Pastoral Care in Education" 2007, t. 25, nr 1, s. 21-25.

Barrow G., Bradshaw E., Newton T., Improving Behaviour and Raising Self-Esteem in the Classroom: A Practical Guide to Using Transactional Analysis, David Fulton Publishers, London 2001.

Berne E., Dzień dobry... i co dalej? Psychologia ludzkiego przeznaczenia, przeł. M. Karpiński, Dom Wydawniczy „Rebis”, Poznań 1998.

Bulhakova K., Sevalneva Z., Rabota stelesnym scenariem s pomố̀ û lûbimoj detskoj skazki, „Edukacyjna Analiza Transakcyjna” 2015, nr 4, s. 36-44, http://dx.doi.org/10.16926/eat.2015.04.02.

Crossman P., Permission and Protection, "Transactional Analysis Bulletin” 1966, nr 5, s. 152-154.

Emmerton N., Newton T., The Journey of Educational Transactional Analysis from Beginnings to the Present, "Transactional Analysis Journal” 2004, t. 34, nr 3, s. 283-291.

Ernst K., Szkolne gry uczniórw. Jak sobie z nimi radzić, przeł. J. Troczyński, Wydawnictwa Szkolne i Pedagogiczne, Warszawa 1991.

55 M. Lubańska, Czy analiza transakcyjna może stać się pomocnym „narzędziem” w pracy nauczyciela? „Edukacyjna Analiza Transakcyjna”2013, nr 2, s. 117-123.

56 J. Górnik, Nauczyciel widziany oczami gimnazjalisty. Wybrane aspekty funkcjonowania nauczycieli gimnazjum w świetle badań własnych, w: Analiza transakcyjna wedukacji, red. J. Jagieła, Częstochowa 2011, s. 211-223.

57 Z. Łęski, Osobowośc nauczyciela w świetle analizy transakcyjnej, w: Analiza transakcyjna w teorii i praktyce pedagogicznej, red. J. Jagieła, Częstochowa 1997, s. 123-135. 
Fine M.J., Covell G., Tracy D.B., The Effects of TA Training on Teacher Attitudes and Behavior, „Transactional Analysis Journal” 1978, t. 8, nr 3, s. 236-240.

Frazier T.L., The Application of Transactional Analysis Principles in the Classroom of a Correctional School, „Transactional Analysis Journal” 1971, t. 1, nr 4, s. 16-20.

Garrison C., Fischer R., Introducing TA in the Public School System, „Transactional Analysis Journal" 1978, t. 8, nr 3, s. 240-246.

Gębuś D., Pierzchała A., Twórczy nauczyciele, pomystowi uczniowie. Osobowościowe korelaty kreatywności nauczycieli z perspektywy analizy transakcyjnej, Wydawnictwo Akademii im. Jana Długosza, Częstochowa 2016.

Górnik J., Nauczyciel widziany oczami gimnazjalisty. Wybrane aspekty funkcjonowania nauczycieli gimnazjum w świetle badań wtasnych, w: Analiza transakcyjna w edukacji, red. J. Jagieła, Wydawnictwo Akademii im. Jana Długosza, Częstochowa 2011, s. 211-223.

Hough P., Teachers and Stroking, „Transactional Analysis Journal” 1971, t. 3, nr 1, s. 38-40.

Jagieła J., Analiza transakcyjna - perspektywy aplikacji pedagogicznych, w: Analiza transakcyjna w teorii i praktyce pedagogicznej, red. J. Jagieła, Wydawnictwo WSP, Częstochowa 1997, s. 17-41.

Jagieła J., Edukacyjna Analiza Transakcyjna w kilku odstonach, Wydawnictwo Akademii im. Jana Długosza, Częstochowa 2012.

Jagieła J., Gry psychologiczne w szkole, Oficyna Wydawnicza Nauczycieli, Kielce 2004.

Jagieła J., Komunikacja interpersonalna w szkole, Wydawnictwo i Hurtownia Rubikon, Kraków 2004.

Jagieła J., Narcystyczna szkoła. O psychologicznej rzeczywistości szkoty, Wydawnictwo Rubikon, Kraków 2010.

Jagieła J., Samoświadomośc nauczycieli w koncepcjach edukacyjnej analizy transakcyjnej, „Prace Naukowe Akademii im. Jana Długosza w Częstochowie. Pedagogika" 2017, t. 26, nr 1, s. 69-83, http://dx.doi. org/10.16926/p.2017.26.06.

Jagieła J., Sarnat-Ciastko A., Dlaczego analiza transakcyjna? Rozmowy o zastosowaniu analizy transakcyjnej w pracy nauczyciela $i$ wychowawcy, $\mathrm{Wy}^{-}$ dawnictwo Akademii im. Jana Długosza, Częstochowa 2015.

Jagieła J., Stownik analizy transakcyjnej, Wydawnictwo Akademii im. Jana Długosza, Częstochowa 2012.

Jagieła J., Znaczenie modelu ptynności funkcjonalnej (FF - functional fuency) Susannah Temple dla rozwoju osobistego $i$ zawodowego nauczycieli z perspektywy edukacyjnej analizy transakcyjnej, Konferencja Internetowa „Edukacja - Analiza - Transakcje”, Akademia im. J. Długosza w Częstochowie, 25.05.2017 r.

Kenney W.J., Problem-Student Effects on Teacher Ego States Behavior, „Transactional Analysis Journal" 1981, t. 3, nr 11, s. 252-253. 
King G., Umiejętności terapeutyczne nauczyciela, przeł. J. Bartosik, Gdańskie Wydawnictwo Psychologiczne, Gdańsk 2003.

Lubańska M., Czy analiza transakcyjna może stać się pomocnym „narzędziem” w pracy nauczyciela? „Edukacyjna Analiza Transakcyjna” 2013, nr 2, s. 117-123.

Łęski Z., Duch w maszynie... Kim dla nas jest komputer? Charakterystyka zjawiska w jezyku analizy transakcyjnej, Wydawnictwo Akademii im. Jana Długosza, Częstochowa 2016.

Łęski Z., Osobowość nauczyciela w świetle analizy transakcyjnej, w: Analiza transakcyjna w teorii i praktyce pedagogicznej, red. J. Jagieła, Wydawnictwo WSP, Częstochowa 1997, s. 123-135.

Newton T., From Transactional Analysis in Education to Educational Transactional Analysis: A Personal Encounter, „Edukacyjna Analiza Transakcyjna” 2016, nr 5, s. 29-37, http://dx.doi.org/10.16926/eat.2016.05.02.

Pankowska D., Analiza transakcyjna w edukacji, czy edukacyjna analiza transakcyjna? - próba porzadkowania znaczeń, „Edukacyjna Analiza Transakcyjna” 2012, nr 1, s. 13-30.

Pankowska D., Metodologia analizy transakcyjnej-przegląd badań, „Przegląd Badań Edukacyjnych" 2008, nr 1, s. 99-115.

Pankowska D., Nauczyciel w perspektywie analizy transakcyjnej, Wydawnictwo UMCS, Lublin 2010.

Pankowska D., Stosowanie analizy transakcyjnej w praktyce szkolnej a zdrowie psychiczne, w: Zdrowa szkota - zdrowy uczeń. Edukacja wobec wspótczesnych zagrożen zdrowia, red. A. Grabowiec, A. Bogucki, A. Bochniarz, Wydawnictwo NeuroCentrum, Lublin 2008, s. 123-134.

Pankowska D., Wykorzystanie analizy transakcyjnej w pracy nauczyciela, $\mathrm{w}$ : Rozpoznania i szkice pedagogiczne, red. D. Jankowska, Wydawnictwo Wyższej Szkoły Humanistyczno-Ekonomicznej, Łódź 2005, s. 51-69.

Pierzchała A., Pasywność szkolna w analizie transakcyjnej. Studium relacji nauczyciele z uczniem (rozprawa doktorska: Wydział Pedagogiczny, Katedra Psychopedagogiki, Akademia Ignatianum w Krakowie, 2013).

Rogulska J., Cechy nauczyciela wygrywajacego, przegrywajacego i niewygrywajacego w świetle analizy transakcyjnej, w: Analiza transakcyjna w teorii i praktyce pedagogicznej, red. J. Jagieła, Wydawnictwo WSP, Częstochowa 1997, s. 157-158.

Ryś M., Konflikty w rodzinie, Centrum Metodyczne Pomocy Psychologiczno-Pedagogicznej MEN, Warszawa 1998.

Sarnat-Ciastko A., Tutoring w polskim systemie oświaty. Badania nad rozwojem metody tutoringu ze szczególnym uwzględnieniem efektów jej stosowania dla nauczyciela i ucznia w ujęciu analizy transakcyjnej, (rozprawa doktorska: Wydział Pedagogiczny, Katedra Psychopedagogiki, Akademia Ignatianum Krakowie, 2014). 
Schachner S., Models of Transactional Analysis in Educational Management, „Edukacyjna Analiza Transakcyjna” 2016, nr 5, s. 35-49, http://dx.doi. org/10.16926/eat.2016.05.03.

Soles S., Social Dynamics: A Study of Classroom Games - Progress Report, „Transactional Analysis Bulletin” 1963, t. 2, nr 8, s. 96-101.

Temple S., The Development of a Transactional Analysis Psychometric Tool for Enhancing Functional Fluency, (nieopublikowana rozprawa doktorska University of Plymouth, 2002).

Temple S., Action on the Functional Model, „EATA Newsletter” 2003, nr 76, s. 4-8.

Temple S., Bringing Up the Child: The Importance of Functionally Fluent Parents, Carers and Educators, w: The Adults Is Parent to the Child: TA with Children E Young People, red. K. Tudor, Russell House, Lyme Regis 2008, https:// westtownapps.com/modx2/section-a/ [dostęp: 7.01.2017].

Temple S., Building Self-awareness, 2004, https://westtownapps.com/modx2/ section-a/ [dostęp: 7.01.2017].

Temple S., Celebrating Functional Fluency and Its Contribution to Transactional Analysis Theory, „Transactional Analysis Journal” 2015, t. 45, nr 1, s. 10-22, doi:10.1177/0362153714568803.

Temple S., Functional Fluency for Educational Transactional Analysts, „Transactional Analysis Journal" 1999, t. 29, nr 3, s. 164-174.

Temple S., Functional Fluency, „Zeitschrift für Transaktionsanalyse” 2002, nr 4, s. 251-269.

Temple S., Mastering "The Tolstoy Effect": A Research Exercise in Linguistic Philosophy, 2012, https://westtownapps.com/modx2/section-a/ [dostęp: 7.01.2017].

Temple S., Mentors, Coaches and the Empowerment Factor: Why Functional Fluency is Important, 2009, https://westtownapps.com/modx2/section-a/ [dostęp: 7.01.2017].

Temple S., TIFF 10 Years On: Life Cycle of a Research Project, „The Transactional Analyst" 2012, t. 4, nr 2, s. 3-17.

Temple S., Update on the Functional Fluency Model in Education, „Transactional Analysis Journal” 2004, t. 34, nr 3, s. 197-204.

Uścińska B., Nauczycielskie okopy Świętej Trójcy, „Edukacyjna Analiza Transakcyjna” 2012, nr 1, s. 67-76.

What Is Transactional Analysis?, https://www.itaaworld.org/what-transactional-analysis [dostęp: 8.02.2017].

\section{ADRES DO KORESPONDENCJI:}

Dr hab. Jarosław Jagieła, prof. AIK

Akademia Ignatianum w Krakowie

Wydział Pedagogiczny

e-mail: yarko1@go2.pl 